\title{
Estimating Micronutrient Status and their Relationship with Other Soil Properties of Rewa District in Fiji
}

\author{
H.K. Sachan ${ }^{1 *}$ and Deeksha Krishna ${ }^{2}$ \\ ${ }^{1}$ Department of Crop Production, College of Agriculture, Fisheries and Forestry, Fiji \\ National University, Koronivia Campus, P.O.Box.1544 Republic of Fiji \\ ${ }^{2}$ Department of Soil Science and Agriculture Engineering, College of Agriculture, Fisheries \\ and Forestry, Fiji National University, Koronivia Campus, P.O.Box.1544 Republic of Fiji \\ *Corresponding author
}

\begin{abstract}
A B S T R A C T
Present study was conducted out during 2015-2016 in Rewa district of Fiji to evaluate

Keywords

Micronutrient, soil property, Rewa, Fiji

\section{Article Info}

Accepted:

20 December 2017

Available Online:

10 January 2018 available micronutrient ( $\mathrm{Fe}, \mathrm{Cu}, \mathrm{Mn}$ and $\mathrm{Zn}$ ) status and their relationship with the soil properties. Fifty seven sites were selected for soil sampling. The available micronutrient (DTPA extractable) viz., $\mathrm{Fe}, \mathrm{Mn}, \mathrm{Cu}$ and $\mathrm{Zn}$ were analyzed using atomic absorption spectrophotometer. The analyzed data revealed that available micronutrients iron $(\mathrm{Fe})$, manganese $(\mathrm{Mn})$ and copper $(\mathrm{Cu})$ were found to be sufficient in most of the soil samples, whereas, available zinc ( $\mathrm{Zn}$ ) was found to be deficient in most of the analyzed samples. Further, availability of $\mathrm{Mn}, \mathrm{Cu}$ and $\mathrm{Zn}$ was found positively correlated with $\mathrm{pH}$ of the soils whereas Fe correlated negatively with $\mathrm{pH}$ of the soil samples. Available $\mathrm{Mn}$ and $\mathrm{Cu}$ were found positively correlated with EC of the soils whereas Fe and $\mathrm{Zn}$ correlated negatively with EC of the soil samples. Available $\mathrm{Fe}, \mathrm{Mn}, \mathrm{Cu}$ and $\mathrm{Zn}$ were found positively correlated with OC of the soils. Findings indicated that soil $\mathrm{pH}$ and organic carbon are the main soil characteristics which control the availability of these micronutrients.
\end{abstract}

\section{Introduction}

Soil fertility, an important factor determining the growth of plants is determined by the presence or absence of plant nutrients.

Nutrients which are required in minute quantities for plant growth are referred as micronutrients. Important role of micronutrients in maintaining soil health and enhancing crop yields is recognized all over the world. Deficiency of micro nutrients has become major constraint to agricultural productivity, stability and sustainability of soils (Bell and Dell, 2008). Although these are required in minute quantities but have significant importance as macronutrients have and play a vital role in the growth and development of plants.

Most of the micronutrients are associated with the enzymatic system of plants and if deficient subnormal growth of plant results which sometime leads to complete failure of crop plants. Flowering and fruiting does not take place in severe deficiency of micronutrients. 
The availability of micronutrients is particularly sensitive to changes in soil environment and affected by organic matter, soil $\mathrm{pH}$ and EC. There is also correlation among the micronutrients contents and abovementioned factors.

With the increased understanding of soils and their quality attributes concept of soil health and quality is consistently evolving. The soil quality is managed by physical, chemical and biological components of a soil and their interaction (Papendick and Parr, 1992).

Plant available micronutrients are affected by presence of macronutrients due to either negative or positive interactions (Fageria, 2001). Indiscriminate uses of macro nutrients may affect uptake of micro nutrients (Dadhich and Somani, 2007).

Soil properties are sensitive to changes in the management and can be used as indicators to measure soil quality (Andrew et al., 2004).Continuous cropping, soils under particular farming may affect soil properties which may modify DTPA extractable micronutrients and their availability to plants. Keeping in view the above facts this research was conducted to study the micronutrients level in relation to other soil properties of the studied area.

\section{Materials and Methods}

\section{Location}

The study was carried out during 2015-2016 in Rewa district of Fiji. The geographical reference of the study area are $18^{\circ} 05^{\prime} 00^{\prime \prime} \mathrm{S}$, $178^{\circ} 20^{\prime} 00^{\prime \prime} \mathrm{E}$ and elevation ranges from 6 to $23 \mathrm{~m}$ above mean sea level. The climate condition of the study site is characterized by wet and dry periods with most rains falling during rainy season from November to April. Average annual rainfall over the area is about 2,500-3,000 mm (Fiji Met, 2013).Soils are acidic in nature and $\mathrm{pH}$ varies from $5.1-6.6$ with low to medium organic carbon and low electrical conductivity $\left(0.01-0.08 \mathrm{~d} \mathrm{Sm}^{-1}\right)$ (Bell et al., 1988).

\section{Soil sampling and analysis}

Fifty seven farmer fields were selected for soil sampling. Representative soil samples were collected considering the heterogeneity of soils by keeping in view the variation in soil type, slope and land use to determine chemical properties and nutrient status. Collected soil samples were filled in labeled zip-lock plastic bags. Soil samples were sent to Fiji Agricultural Chemistry Laboratory for analysis. Samples were air dried and carefully sieved with $2 \mathrm{~mm}$ diameter mesh.

Soil samples were analyzed for $\mathrm{pH}$ and EC using EUT tech $\mathrm{pH}$ meter and EC 300, respectively. The available micronutrients Fe, $\mathrm{Mn}, \mathrm{Cu}$ and $\mathrm{Zn}$ of soil samples were extracted with a DTPA solution (Lindsay and Norvell, 1978). The concentration of micronutrients in the extract was determined using atomic absorption spectrophotometer (AAS).

\section{Statistical analysis}

The relationship between different soil physicochemical properties and available micronutrients were determined using statistical software SPSS to calculate correlation coefficient.

\section{Results and Discussion}

Textural class of soils of study area was sandy clay loam and clay loam Soil Taxonomy (1975).The soil $\mathrm{pH}$ varied among various sites from 4.9 to 7.0. The soils of the study area are acidic in nature with the mean $\mathrm{pH}$ of 5.9 (Table 1) which falls under moderately acidic rating of soil pH (5.6-6.0) (Bruce and Raymond, 1982). Low values of $\mathrm{pH}$ are due to acidic parent material, continuous rainfall that 
leaches most of bases throughout the year, decomposition of organic matter further decrease the soil $\mathrm{pH}$ (Miyauchi and Hayashi, 1985).

Electrical conductivity (EC) of the soils varied from $0.02-0.70 \mathrm{dSm}^{-1}$ with a mean value 0.10 $\mathrm{dSm}^{-1}$. On the basis of limits suggested by Muhr et al., (1965) for judging soil salt problems, all samples were found normal (EC $\left.<1.0 \mathrm{dSm}^{-1}\right)$.

This normal electrical conductivity may be ascribed as lower base concentration and leaching of salts from the soils. Organic carbon (OC) values of the soils varied from 0.8 to $4.3 \%$ with the mean value of $2.1 \% .96$ percent soil samples recorded organic carbon below the range (4-10\%) and found deficient
(Table 1). The range and mean values of analyzed soil samples given in Table 1 . On the basis of critical limit suggested by Lindsay and Norvell (1978) of DTPA extractable Iron $(\mathrm{Fe}), 94.7$ per cent soil samples were found sufficient and 3.5 per cent soil samples were recorded as deficient (Fig. 1). The content of DTPA extractable Fe varied from 3-153 mg $\mathrm{kg}^{-1}$ with an average value of $26.25 \mathrm{mg} \mathrm{kg}^{-1}$.

The DTPA extractable Manganese (Mn) in the soil samples varied from 1 to $48 \mathrm{mg} \mathrm{kg}^{-1}$ with the mean value of $13.14 \mathrm{mg} \mathrm{kg}^{-1}$ (Table 1). Based on the critical limit suggested by Sakal et al., (1985), 91 per cent soil samples were found sufficient and 5 per cent soil samples were found to be deficient in available $\mathrm{Mn}$ (Fig. 1).

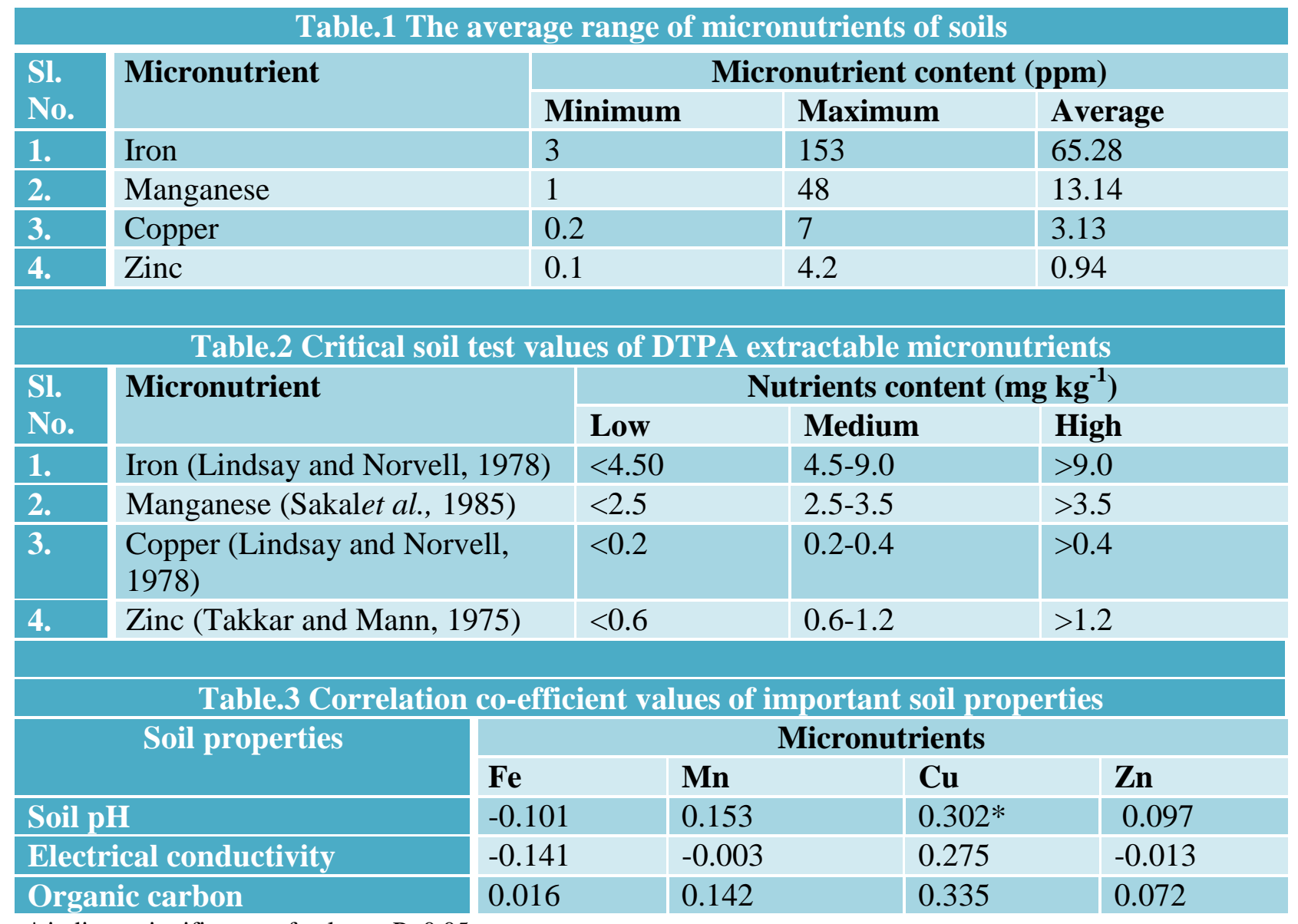


Fig.1 Micro nutrients status of soils based on their critical range

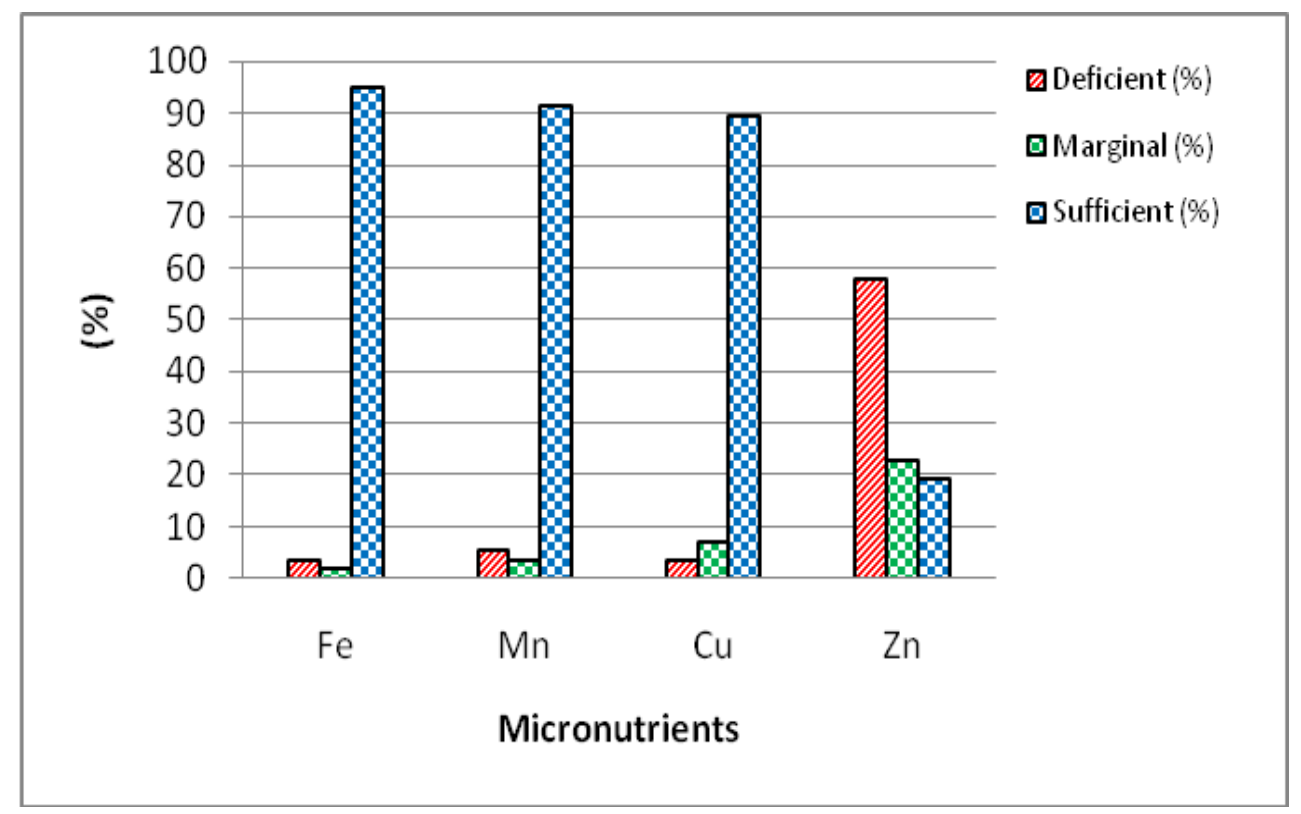

The DTPA extractable Copper $(\mathrm{Cu})$ content of the soil samples varied from $0.2-7.0 \mathrm{mg} \mathrm{kg}$ ${ }^{1}$ with mean value of $3.13 \mathrm{mg} \mathrm{kg}^{-1}$ (Table 1 ). Based on the critical limit suggested by Lindsay and Norvell (1978), 89 per cent soil samples were found sufficient and 4 per cent soil samples were found to be deficient in available $\mathrm{Cu}$ (Fig. 1).

The DTPA extractable Zinc (Zn) in the soil samples varied from $0.1-4.2 \mathrm{mg} \mathrm{kg}^{-1}$ with mean value of $0.94 \mathrm{mg} \mathrm{kg}^{-1}$ (Table 1). On the basis of critical limit suggested by Takkar and Mann, (1975) 58 per cent samples were deficient in DTPA extractable Zn (Fig. 1) that require $\mathrm{Zn}$ application for optimum production and to get full benefit of applied NPK fertilizers in the studied area, 23 per cent samples were marginal and 19 per cent of the samples were sufficient in $\mathrm{Zn}$ availability.

All the investigated micronutrients are influenced by the soil environment (Lindsay and Norvell, 1978). Soil $\mathrm{pH}$ has been comprehensively identified as the single most important soil factor controlling the availability of micronutrients in soil.
The correlation coefficient between available micronutrients shown in Table 3.Availability of $\mathrm{Mn}, \mathrm{Cu}$ and $\mathrm{Zn}$ was found positively correlated $\left(r=0.153, r=0.302^{*}, r=0.097\right)$ with $\mathrm{pH}$ of the soils whereas $\mathrm{Fe}$ correlated negatively $(\mathrm{r}=-0.101)$ with $\mathrm{pH}$ of the soil samples. Available $\mathrm{Cu}$ was found positively correlated $(\mathrm{r}=0.275)$ with EC of the soils whereas $\mathrm{Fe}, \mathrm{Mn}$ and $\mathrm{Zn}$ correlated negatively $(\mathrm{r}=-0.141, \mathrm{r}=-003 \mathrm{r}=-0.013)$ with EC of the soil samples. Availability of $\mathrm{Fe}, \mathrm{Mn}, \mathrm{Cu}$ and $\mathrm{Zn}$ was found positively correlated $(\mathrm{r}=0.016$, $\left.\mathrm{r}=0.141, \mathrm{r}=0.335^{*}, \mathrm{r}=0.072\right)$ with $\mathrm{OC}$ of the soils (Table 3 ).

The study revealed that available micronutrients iron $(\mathrm{Fe})$, manganese $(\mathrm{Mn})$ and copper $(\mathrm{Cu})$ were found to be sufficient in most of the soil samples, whereas, available zinc ( $\mathrm{Zn})$ was found to be deficient in most of the analyzed samples.

Further, availability of $\mathrm{Mn}, \mathrm{Cu}$ and $\mathrm{Zn}$ was found positively correlated with $\mathrm{pH}$ of the soils whereas $\mathrm{Fe}$ correlated negatively with $\mathrm{pH}$ of the soil samples. Available $\mathrm{Mn}$ and $\mathrm{Cu}$ were found positively correlated with EC of 
the soils whereas $\mathrm{Fe}$ and $\mathrm{Zn}$ correlated negatively with EC of the soil samples. Available $\mathrm{Fe}, \mathrm{Mn}, \mathrm{Cu}$ and $\mathrm{Zn}$ was found positively correlated with OC of the soils. Findings indicated that soil $\mathrm{pH}$ and organic carbon are the main soil characteristics which control the availability of these micronutrients.

\section{Acknowledgements}

Authors are highly grateful to the Fiji National University for providing necessary facility to carry out this work. Thanks are also due to the Director Research, Koronivia Research Station for providing the laboratory facilities to analyze the soil samples.

\section{References}

Andrew, S.S., Karlen, D. L. and Cambardella, C.A. 2004. The soil management assessment framework: A quantitative soil quality evaluation method. Soil Science Society American Journal, 68, 1945-1962.

Bell, R.W. 1988. Nutrient deficiencies in four acid soils from south east VitiLevu, Fiji Agricultural Journal 50, 7-13.

Bell, R.W. and Dell, B. 2008. Micronutrients for Sustainable Food, Feed, Fiber and Bio energy Production. IFA, Paris, France

Bruce, R.C. and Rayment, C.E. 1982. - Analytical methods and interpretations used by the Agricultural Chemistry Branch for soil and land use surveys. Queensland Department of Primary Industries Bulletin QB82004.

Dadhich, S.K. and Somani, L.L. 2007. Effect of integrated nutrient management in soybean -wheat crop sequence on the yield, micronutrient uptake and postharvest availability of micronutrients on typicustochrepts soil. ActaAgron.
Hungarica, 55 (2): 205-216.

Fageria, V. D. 2001. Nutrient interactions in crop plants. J.PlantNutr., 24 (8): 1269-1290.

Fiji, Met 2013. Fiji meteorological services http://www.met.gov.fj/index.php.

Kinyangi, J. 2007. Soil Health and Soil Quality: A Review. http://ccafs.cgiar.org/about/whowe-are/our-staff/researchers/regional program- leader/james-kinyangi.

Lindsay, W. L. and Norvell, W. A. 1978. Development of DTPA soil test for $\mathrm{Zn}, \mathrm{Fe}$, $\mathrm{Mn}$ and Cu. Soil Sci. Soc. American J., 42: $421-428$.

Miyauchi, N and M. Hayashi 1985. Note on some acid sulphate soils in Fiji. Kogoshima University Research Centre. South Pacific 5, 175-178.

Muhr G. R., Datta, N. P., Shankara, N., Dever, F., Lecy, V.K. and Donahue, R. R. 1965. Soil testing of India, $2^{\text {nd }}$ Edn. US Agency for International Development, New Delhi: 120.

Papendick, R. I. and Parr, J., 1992. Soil quality the key to sustainable agriculture. Am. J. Altern. Agric. 7, 2-3.

Sakal, R., Singh, A.P., Singh, B.P., Sinha, R.B., Jha, S.N. and Singh, S.P. 1985. Distribution of available micronutrient cations in calcareous soils as related to certain soil properties, J. Indian Soc. Soil Sci., 33: 672675.

Singh, Indra Raj 2016. Micronutrient level in relation to other soil properties of Koronivia, Fiji. Asian J. Soil Sci., 11 (1): 155-158: DOI: 10.15740/HAS/AJSS/ 11.1/155-158.

Takkar, P.N. and Mann, M.S. 1975. Evaluation of analytical methods for estimating available zinc in major soil series of Ludhiana, India. Agrochemica, 19: 420.

\section{How to cite this article:}

Sachan, H.K. and Deeksha Krishna. 2018. Estimating Micronutrient Status and their Relationship with Other Soil Properties of Rewa District in Fiji. Int.J.Curr.Microbiol.App.Sci. 7(01): 2808-2812. doi: https://doi.org/10.20546/ijcmas.2018.701.335 